TECHNICAL TRANSACTIONS 2/2017

CZASOPISMO TECHNICZNE 2/2017

ENVIRONMENTAL ENGINEERING

DOI: $10.4467 / 2353737$ XCT.17.021.6214

\author{
Justyna Kwaśny (kwasny.justyna@gmail.com) \\ Wojciech Balcerzak \\ Institute of Water Supply and Environmental Protection, Department of Environmental \\ Engineering, Cracow University of Technology
}

\title{
CHARACTERISTICS OF SELECTED METHODS FOR THE SYNTHESIS \\ OF NANOMETRIC ZIRCONIUM OXIDE - CRITICAL REVIEW
}

\author{
CHARAKTERYSTYKA WYBRANYCH METOD SYNTEZY \\ NANOMETRYCZNEGO TLENKU CYRKONU - PRZEGLĄD
}

\begin{abstract}
High chemical stability, resistance to changes in the $\mathrm{pH}$, pressure and temperature meant that zirconium oxide is widely used in many fields. It is used in water treatment and waste water treatment processes, as well as air purification. In this paper, selected methods of nano-zirconia synthesis in liquid phase were characterized. These methods include, among others, the microemulsion method. Based on literature data, the advantages and difficulties associated with the use of each method are presented, in order to answer the question of which method of nanometric zirconium oxide synthesis in the liquid phase is the most advantageous. The authors also pointed out some directions of development for the discussed methods, which relate to, among others, solvent change and the use of additives in the form of polymers.
\end{abstract}

Keywords: nano zirconia, hydrothermal method, synthesis, microemulsion method

\section{Streszczenie}

Wysoka stabilność chemiczna, odporność na zmiany pH, ciśnienia i temperatury sprawily, że tlenek cyrkonu znajduje szerokie zastosowanie $\mathrm{w}$ wielu dziedzinach. Jest stosowany $\mathrm{w}$ procesach uzdatniania wody i oczyszczania ścieków, a także w oczyszczaniu powietrza. W niniejszej pracy scharakteryzowano wybrane metody syntezy nanotlenku cyrkonu w fazie ciekłej. Wśród grupy tych metod wyróżnia się m.in. metodę mikroemulsji. Na podstawie danych literaturowych przedstawiono zalety i trudności związane ze stosowaniem poszczególnych metod, aby móc odpowiedzieć na pytanie, która metoda syntezy nanometrycznego tlenku cyrkonu, w fazie ciekłej, jest najkorzystniejsza. Autorzy wskazali również na pewne kierunki rozwojowe omówionych metod, które wiążą się m.in. ze zmianą polarności rozpuszczalnika i stosowaniem dodatków w formie polimerów.

Słowa kluczowe: nanotlenek cyrkonu, metoda hydrotermalna, synteza, metoda mikroemulsji 


\section{Introduction}

Special properties of zirconia and its wide application mean that methods of its preparation are constantly being developed. The direction of this expansion results from the need to obtain materials with improved performance associated with the mechanical and thermal strength, and chemical stability.

Nano-sized zirconia can be obtained in both the gas and liquid phases, as well as from the solid. There are two general groups of methods for obtaining nanomaterials. These methods are "bottom-up" and "top down" [1-3]. "Bottom-up" methods rely on building a nanometric structure from below, that is, from the level of individual atoms or molecules. "Top down" methods, as methods from above, rely on grinding a solid on a micrometer structure to nanometer sizes 15). Methods of synthesis in the gaseous and liquid phases are among the "bottom-up" methods, and methods of synthesis in the solid state, in most cases, are classified as "top down" methods. Solid state synthesis, exemplified by mechanochemical synthesis, is based on the fact that chemical reactions are induced by mechanical energy. Whereby there is a reduction in the temperature of a chemical reaction [4-6].

\section{Synthesis of nanometric zirconia in the vapor phase}

Methods of synthesis in the gaseous phase are divided into physical vapor deposition PVD [7], which involves the condensation in an inert gas [8], and chemical vapor deposition CVD [9-12]. In this method, volatile compounds are heated to form vapor, mixed and transported using a carrier gas to a substrate, on which surface crystallization of the product takes place. In these methods, due to the determination of the appropriate conditions, the pair (usually oversaturated) becomes thermodynamically unstable, and therefore the formation of the condensed phase by homogeneous nucleation of solid phase occurs. The process is carried out with a high degree of vapor supersaturation resulting in an increased density of nucleation during the growth of nucleating agents. The key issue to achieve nanometric product is a fast extinguishing system, completed within a reasonable time, which is done by removing the source of supersaturation or extending the kinetics (cooling circuit), with the result that the particles do not grow [3].

Among these methods, various techniques for depositing material from a gaseous phase are highlighted. For example, it may be a magnetron sputtering [13, 14], plasma spraying [1520], which consists in creating a plasma of high temperature, to $2000 \mathrm{~K}$, and then delivered thereto, by a carrier gas, the material in the form of a powder that will be deposited. Hass et al. [15] concluded that a ceramic coating obtained this way may exhibit less consistency with the substrate and be characterized by higher porosity and non-uniform distribution of the pore volume fraction and shape. This fact significantly affects the thermal conductivity of the material. For another technique, which is the electron beam - physical vapor deposition (EB-PVD), the elements are rotated in the vapor plume, so that condensation of vapor molecules generally occurs unevenly. The result is a layer consisting of a porous, strongly 
textured columnar structures of different lengths. Such a layer structure favors its flexibility and increases the thermal conductivity. Another example of physical vapor deposition is an electron beam - directed vapor deposition (EB-DVD) in which the material is not rotated. This results in a layer with a columnar structure, but with similar porosity, shape and length [15]. There is also a technique, which uses stellarator, specifically heliotron, known as the solar physical vapor deposition (SPVD) method [21].

Phase synthesis methods require specific gas pressure and temperature. Therefore, it is necessary to use specific and expensive equipment as well as facilities, among which plasma burners and magnetron stand out [13].

Methods for chemical synthesis from the gas phase can also be divided into several techniques. It should be noted that these methods differ mainly in the way of introducing the precursor and in the type of thermal energy source. In this group, chemical synthesis in the gaseous phase with the use of organometallic precursors [11,22], liquid-injection chemical vapor deposition [23] and vapor phase hydrolysis [24] can be distinguished. And in the case, where the precursor is not introduced in the form of a vapor, but in the form of tiny droplets generated by a nebulizer, e.g. ultrasonic, spray pyrolysis techniques $[25,26]$ are highlighted, as well as others, e.g. aerosol assisted chemical vapor deposition (AACVD) [27].

Methods of synthesis and deposition from the gaseous phase result in the acquisition of a material with high purity. They allow to obtain the product, both in powder form and in the form of a layer applied to the substrate. The biggest limitation in the application of these methods is the need to use expensive and complex equipment.

\section{Examples of the synthesis of nanometric zirconia in the liquid phase}

Among liquid-phase synthesis methods, inter alia co-precipitation [28-31], hydrothermal methods [32-42], sol-gel method [43-48] and microemulsion method [49-56] are distinguished.

\subsection{Synthesis of nano-zirconia by co-precipitation}

Co-precipitation methods can be classified as conventional methods for the preparation of nanocrystals. Depending on the reaction conditions and substrates, the method allows to obtain particles with different diameters. Crystalline, non-agglomerated, nano-sized $\mathrm{Al}_{2} \mathrm{O}_{3}-\mathrm{ZrO}_{2}$ prepared by $\mathrm{Zhou}$ and coworkers [57] can be cited as examples, which had a particle diameter of about $7 \mathrm{~nm}$, followed by tetragonal zirconia polycrystals stabilized by yttrium ( $3 \mathrm{~mol} \%$.) with a diameter of $21.3 \mathrm{~nm}$ obtained by Hsu et al. [58] as well as lead catalysts based on $\mathrm{CdO}_{2}-\mathrm{ZrO}_{2}$ (in a single phase) with a diameter of 5.2 to $28.9 \mathrm{~nm}[59]$ and the $\mathrm{Y}_{2} \mathrm{O}_{3}-\mathrm{ZrO}_{2}$ powder with a crystal diameter of 53-109 $\mu \mathrm{m}$ obtained by Aruna et al. [60].

The greatest advantage of the precipitation method is the possibility to obtain the product in amounts consisting of grams [28], and the ability to use cheaper and easier to 
acquire equipment and nano-particle precursors $[58,61]$. The disadvantage of this method is the inability to control the size of the resulting nanoparticles [28]. In order to reduce the agglomeration of nanoparticles, Wang et al. [61] proposed the synthesis of nano- $\mathrm{ZrO}_{2}$ based on the direct precipitation using ethanol instead of water. The authors [61] used water, ethanol and water-ethanol mixtures at various ratios by volume, $\mathrm{ZrOCl}_{2}$ i $\mathrm{NH}_{3} \cdot \mathrm{H}_{2} \mathrm{O}$, except that the surfactant was applied in the form of poly(ethylene glycol) 800 - PEG 800 . Depending on the solvent used, products with different grain size and dispersion were obtained. The authors [61] have shown that the use of ethanol-limited agglomeration of particles, and no addition of PEG 800, additionally increase this effect [61].

\subsection{Synthesis of nano-zirconia by hydrothermal methods}

Hydrothermal methods are a group of methods among which hydrothermal decomposition, hydrothermal crystallization, homogeneous hydrothermal precipitation, microwave hydrothermal synthesis and hydrothermal synthesis, assisted by ultrasound and also hydrothermal synthesis under supercritical conditions [62] as well as hydrothermal oxidation [35] are highlighted. Hydrothermal methods relate to processes at hydrothermal conditions, which depend on temperature, pressure, $\mathrm{pH}$, redox potential and environmental activity of the ingredients, which depends on the dielectric constant and the dissociation of water $[35,62]$. It should be emphasized that, already in 1980, using the hydrothermal method, nanocrystalline powders based on $\mathrm{ZrO}_{2}$ were obtained.

The hydrothermal method can be based on crystallization in an aqueous solution under increased pressure and at a temperature below the critical point of water. This process is conducted in an autoclave, where the substance concentration gradient is determined. The aterial is arranged in the lower part of the autoclave. This material is heat-solubilized, then travels up through the autoclave wherein at a lower temperature, due to the saturation of the solution, the crystallization of crystals occurs. Hydrothermal synthesis refers to synthesis of a compound in the hydrothermal solution under the influence of temperatures above $100^{\circ} \mathrm{C}$ and at a pressure above 1 atmosphere. For the synthesis of zirconium oxide (IV), the essence of the method is the production of ceramic sols, by chemical reaction in an aqueous or organic-aqueous solution, while applying heat and pressure, in the presence of an alkali or acid, which have a pseudo catalytic effect on the reaction [37]. Hydrothermal synthesis allows to obtain the three crystalline forms of zirconium oxide (IV): monoclinic, tetragonal [35] and the cubic [37], at the same time, with a lower rate of the monoclinic form. Depending on the reactants and conditions of the synthesis, it is possible to obtain particles with different diameters. The impact of metal precursors is significant, which has been demonstrated by the Caillot and co-workers [63] and derived by their surface characteristics and ICP analysis results compiled (based on [63]) and reported graphically in Figure 1. Based on the graph, it can be concluded that the addition of cerium, lanthanum and titanium resulted in an increase in the surface area of the zirconia products. However, it should be emphasized that this increase was not identical with the increasing proportion of each metal oxide in the final product. 


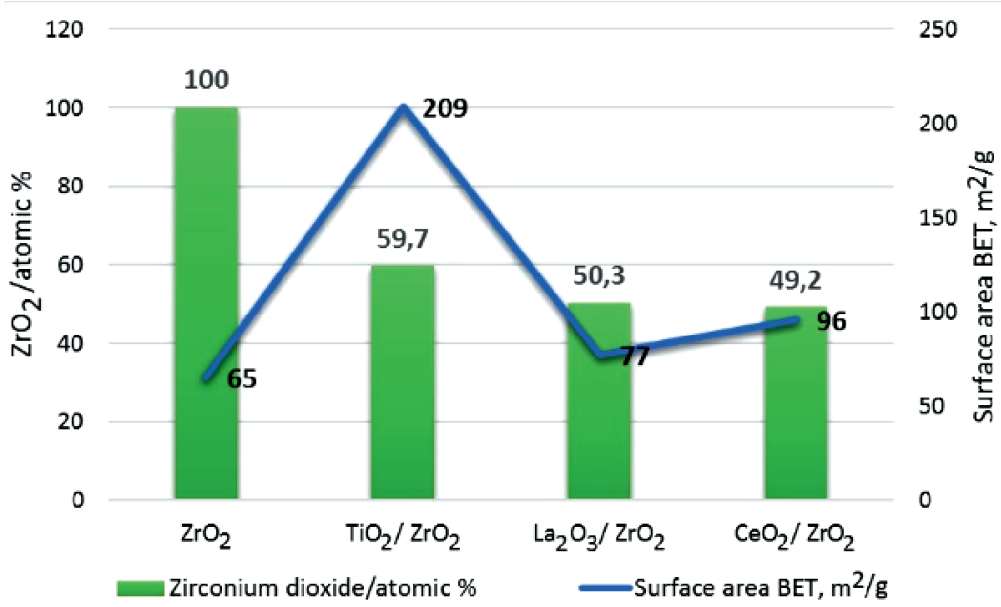

Fig. 1. Effect of metal precursor addition on the surface area of zirconia, on the basis [63]

Hydrothermal methods have both advantages and disadvantages. Among the advantages of these methods, we must distinguish the ability to conduct the process at low temperatures (max. $374^{\circ} \mathrm{C}$ ), no need for a thermal treatment at high temperatures, high purity and quality of the products obtained, a small dispersion particle size, the ability to control the shape of the grains and nucleating agents. The increase in nucleation may be controlled by varying the concentration, increasing or decreasing the hydrolysis temperature and also increasing the duration of hydrolysis as well as by the introduction of surfactants during dehydration and changes in $\mathrm{pH}$ [62]. In contrast, the disadvantages of the hydrothermal methods include a high degree of complexity of the apparatus and its cost, as well as an inability to direct the observation of the process.

The microwave hydrothermal method, also called the solvothermal method, is a type of hydrothermal methods, which use microwave energy as a heat source. As a result, the reaction mixture does not have direct contact with the heating element and the time of whole process is considerably reduced. With the increase in pressure, the particles diameter increases and the monoclinic phase content in the product decreases. The result of the process is obtaining a material of high purity whose grain diameter is in the range of 5-50 $\mathrm{nm}[41,42]$.

\subsection{Synthesis of nano-zirconia by the sol-gel method}

Another example of methods for the synthesis of nanometric zirconia is the sol-gel method. This type of chemical synthesis based on the specific chemical reactions taking place in solution, and in a further step on a series of transformations starting solution - first in the form of sol, then gel, ending with the conversion of the gel into a solid amorphous or crystalline structure $[43,44]$. Therefore, this method is used to produce glass $[45,64,65]$. The conversion of the sol into gel is based on a dehydrated colloidal solution of material hydroxide particles, thereby producing a gelatinous substance, called the gel. These reactions are often carried 
out with the use of alkoxides of various elements as starting materials [43]. In this case, the formation of a sol - gel system based on the hydrolysis and condensation reactions. The first reaction taking place in solution comprises of the hydrolysis (breakup) of alkoxy bond in the molecule Me-OR and the creation of hydroxyl bonds Me-OH. This reaction precedes in a mutual solvent for the alkoxide and water, with the participation of a suitable catalyst. This is followed by a condensation reaction between hydroxyl and alkoxy groups or two hydroxyl groups, resulting in the formation of bond type $(\mathrm{RO})_{\mathrm{n}-1} \mathrm{Me}-\mathrm{O}-\mathrm{Me}(\mathrm{OR})_{\mathrm{n}-1}$, where $n$ is the number of alkoxy groups in the molecule of alkoxide. The hydrolysis and condensation reactions occurring in parallel result in an increase in the number of Me-O bonds, which leads to initiation of the gelation process. The course of the described reaction depends on the temperature, $\mathrm{pH}$, water and solvent content, polarity of the solvent, and type and concentration of the used catalyst. The catalysts, which are used in the sol-gel method, may be acidic or alkaline. In the first case, inorganic or organic acids are used, and in the second, it is mostly ammonium hydroxide. The increase in the number of Me-O bonds is the cause of the partial polymerization of alkoxides, which subsequently agglomerate. This results in an increase in the viscosity of the system, which, during prolonged drying, is converted to a gel by evaporation of the solvent [43]. In further steps, calcination is carried out.

The advantages of the sol-gel process include simplicity of use and low equipment cost, high purity raw materials and a high degree of homogeneity of the microstructure, the relatively low process temperature in comparison with synthesis methods from the gas phase like PVD (Physical Vapour Deposition) and CVD (Chemical Vapour Deposition), no toxic waste or its low participation, as well as the ability to receive color layers [43, 44]. In contrast, the disadvantages of this method include the high cost of chemical reagents, as well as what is one of the key issues - stability of technological parameters [43].

The sol-gel method is often used to receive various types of ceramic coatings. For the preparation of nanocrystalline sulfated zirconium oxide (IV), the process can be carried out in two stages. In the first step, hydrolysis and condensation take place, and in the second, sulfation with sulfuric acid or ammonium sulfate occurs. Whereas in a one-step method, the mentioned chemical reactions take place simultaneously [46]. The one-step synthesis method proposed by Mishra and colleagues [46] allowed to obtain a product with a particle diameter of $11-16 \mathrm{~nm}$, specific surface area of $101-118 \mathrm{~m}^{2} / \mathrm{g}$ and a diameter and pore size that were respectively $0.152-0.190 \mathrm{~cm}^{3} / \mathrm{g}$ and $58-62 \AA$. These parameters (except for the diameter and pore size) are not very different from those, which characterize the product obtained by the two-step method. Particle diameter, surface area, pore diameter and pore size of the sulfated zirconium oxide (IV) were, respectively, $11 \mathrm{~nm}, 101 \mathrm{~m}^{2} / \mathrm{g}, 0.087 \mathrm{~cm}^{3} / \mathrm{g}$ and $37 \AA$ [46]. All the obtained products were characterized by a tetragonal structure. Akkarin et al. [47], using the solgel method, have received nanocrystalline sulfated zirconium oxide (IV) on mesoporous silica used as a carrier. Zirconium acetylacetonate and tetraethyl orthosilicate were used as reactants. The sulfation reaction was carried out using in situ $\mathrm{H}_{2} \mathrm{SO}_{4}$. The authors [47] have also studied the effect of the amount of sulfuric acid added, as the $\mathrm{S} / \mathrm{Zr}$ mole fraction, on structural properties. It has been shown that, with the mole fraction of $0-0.45$, two dominant pore sizes, i.e. $3.5 \mathrm{~nm}$ and $10 \mathrm{~nm}$, are observed. In contrast, when the $\mathrm{S} / \mathrm{Zr}$ mole fraction is more 
than 0.6 , the pores with a diameter below $4.0 \mathrm{~nm}$ become negligible. It has also been observed that the increase of the $\mathrm{S} / \mathrm{Zr}$ mole fraction in the range of 0.3 to 0.6 increased the gelling time, which resulted in a decrease of the pore volume [47]. De la Rosa et al. [48] received zirconium oxide (IV) doped with $0.5 \mathrm{wt} \%$. La, Mn and Fe based on the sol-gel method. They analyzed the influence of the type of metallic precursor on the crystalline phase. The authors used zirconium alkoxide and precursors in the form of a metal acetate as substrates. The resulting products were characterized by a surface area in the range of 1.5 to $5.0 \mathrm{~m}^{2} / \mathrm{g}$ and a pore size from 5 to approx. $60 \mathrm{~nm}$. It has been shown that the zirconia doping with lanthanum and manganese promotes the formation of the monoclinic phase, and the dopant lanthanum-iron results in the formation of the tetragonal phase of $\mathrm{ZrO}_{2}$. The resulting products were used in the catalytic combustion of trichlorethylene, so their thermal characteristics were carried out. The authors found an approximately $20 \%$ loss of mass when the gelation temperature was $80-200^{\circ} \mathrm{C}$. This weight loss may be associated with the evaporation of physically absorbed water and ethanol from the solids. The second weight loss was observed at $200-380^{\circ} \mathrm{C}$, which was explained as being the result of the alkoxy group oxidation [48]. The effect of the addition of the precursor metal on the zirconium dioxide crystal structure was also studied by Miyoshi et al. [66]. The authors demonstrated that even a small addition of yttrium ( $1 \mathrm{~mol} \%)$ stabilizes the tetragonal phase. The effect of increasing the concentration of yttrium is the creation of equilibrium shares of monoclinic and tetragonal phases. The authors observed this effect in $\mathrm{Zr}_{0.96} \mathrm{Y}_{0.04} \mathrm{O}_{1.98}$. This share phase change with increasing heat treatment temperature to the disadvantage of the monoclinic phase - in $1273 \mathrm{~K}$ the amount of this phase is negligible. For $\mathrm{Zr}_{0.84} \mathrm{Y}_{0.16} \mathrm{O}_{1.92}$ both before and after heat treatment, the dominant phase in the crystal was a cubic phase [66].

The sol-gel method is an effective method for obtaining thin layers of ceramic. This has been proven in many publications $[44,45,67,68]$, but also by a combination of hydrothermal methods leading to the acquisition of nanocrystalline powders $[32,36]$.

\subsection{Synthesis of nano-zirconia by microemulsion method}

The microemulsion method has already been successfully applied for the preparation of nanoparticles by Boutonnet and co-workers [69] in 1982. The synthesis products by this technique have a uniform size distribution and dispersion. The essence of the method involves mixing together two microemulsions, where there are various reagents in the drops. Then, as a result of mixing, the emulsion liquid droplets collide and exchange reagents. The step of nucleation and crystal growth of product occurs within the droplets and is limited by their diameter (average diameter $=50 \mathrm{~nm}$ ). In further steps, the reactions of the precipitation and calcination take place. A microemulsion is thermodynamically stable, isotropic and transparent dispersion, which consists of two mutually immiscible liquids - water and oil [51]. The third component of the emulsion is an emulsifier, which is introduced in the form of one or two surfactants with the assumption that the quantity does not exceed 10-15 mass\%. of the entire system weight [56]. Into microemulsion, the addition of a co-surfactant is introduced. It prevents the so-called phenomenon of "Ostwald ripening". It occurs when the 
monomer particles leak from small droplets of the dispersed phase into large particles through the continuous phase [56]. There are two main types of microemulsion - oil in water microemulsion $(\mathrm{o} / \mathrm{w})$ and water-in-oil (w/o) [55]. Most of the examples of zirconia nanoparticle synthesis using the microemulsion technique takes place in a water-in-oil system $[53,54,70]$, but there are also known synthesis methods in an oil-in-water system, which are gaining in importance due to the possibility of the use of anionic surfactants [50,52]. In the $\mathrm{o} / \mathrm{w}$ microemulsion metal precursors and the precipitating agent are dissolved in the continuous phase, while in the w/o microemulsion, they are inside the droplets of the dispersed phase. Therefore, in the technique based on $\mathrm{o} / \mathrm{w}$ microemulsion, the synthesis process is different. In a first step, a microemulsion is formed, and then metal cations, which will be adsorbed at the oil-water interface, are added. This is caused by Coulomb forces - the attraction between the metal cation and surfactant anion. The fact that the ions are strongly solvated in polar solvents is also not without significance. As a result, the cation is positioned at the oil-water interface, because it is stabilized by both water and surfactants molecules. After adding the flocculation agent to the system, the equilibrium is destroyed and consequently, at the interface, plurality of product particles are formed [52]. In the w/o microemulsions, the size and shape of the products depend largely on the used surfactant $[37,41,42,70]$, which is shown in Table 1.

Table 1. Examples of the zirconium dioxide synthesis using w/o microemulsion

\begin{tabular}{|c|c|c|c|c|c|}
\hline \multicolumn{3}{|c|}{ Microemulsion components } & \multirow{2}{*}{$\begin{array}{c}\text { Particle size } \\
\text { (diameter) }[\mathrm{nm}]\end{array}$} & Characteristics & Lit. \\
\hline $\begin{array}{c}\text { Oil phase } \\
\text { Heptane and } \\
\text { cyclohexane }\end{array}$ & $\begin{array}{c}\text { Water phase } \\
\text { solution of } \\
\text { zirconium salt }\end{array}$ & $\begin{array}{c}\text { Span } 80+\text { Arlacel } 83 \\
+ \text { isopropanol }\end{array}$ & $2 \cdot 10^{3}-8 \cdot 10^{3}$ & spherical shape & 71,72 \\
\hline $\begin{array}{c}\text { Xylene } \\
\text { zircolution of } \\
\text { yttrium nitrate }\end{array}$ & Tween 80 & $0,3 \cdot 10^{3}-1,0 \cdot 10^{3}$ & $\begin{array}{c}\text { fusiform and } \\
\text { spherical shape }\end{array}$ & 73 \\
\hline Cyclohexane & $\begin{array}{c}\text { solution of } \\
\text { zirconium salt }\end{array}$ & $\begin{array}{c}\text { Triton X-100/ } \\
\text { pentanol }\end{array}$ & $4-20$ & $\begin{array}{c}\text { fusiform shape } \\
\text { and monoclinic }\end{array}$ & 70 \\
\hline Cyclohexane & $\begin{array}{c}\text { solution of } \\
\text { zirconium salt }\end{array}$ & $\begin{array}{c}\text { Triton X-100/ } \\
\text { hexyl alcohol }\end{array}$ & $30-40$ & spherical shape & 70 \\
\hline n-Octan & ZrOCl solution & $\begin{array}{c}\text { Span } 80 / \text { Triton } \\
\text { X-100/n-hexyl } \\
\text { alcohol }\end{array}$ & $7.2-23.7$ & spherical shape & 53 \\
\hline
\end{tabular}

The microemulsion method is a versatile technique for the synthesis of nanoparticles, which allows to control properties, such as size, geometry, morphology, homogeneity and surface [50]; therefore, it is regarded as one of the best synthesis methods. In addition, its application does not require the use of expensive and complicated laboratory equipment. 


\section{Conclusions}

Nano-sized zirconia may be obtained from all phases of matter, ie. from the gas and the liquid phase as well as the solid. Methods for obtaining it are chosen based on the chemical synthesis or physical processes. This article discusses some methods for the synthesis of nano-zirconium dioxide from the liquid phase, focusing on the co-precipitation method, hydrothermal methods, sol-gel method and the microemulsion method. All of these methods have advantages and disadvantages. A great advantage of most of them is the lack of the need to use expensive and complicated laboratory equipment, the only exception being the hydrothermal method. Most liquid methods do not require high processing temperatures, unlike the gas phase synthesis methods. Products can be obtained both in the form of powders as well as layers deposited on the substrate. The big advantage is the ability to conduct modification of the final structure of the material, e.g. by applying suitable metal precursors and by carrying out the synthesis under appropriate conditions and in the presence of certain chemicals, e.g. surfactants. Thus, there are several ways to modify the methods of nanometric zirconia synthesis. Based on the cited literature, certain trends of the methods discussed can be seen as well. Hydrothermal methods are supported by the action of microwave energy and ultrasound. It also seems that, in the near future, interest in polymers, substances limiting the agglomeration of particles in aqueous solutions, will increase. Previously quoted example - PEG 800, which did not just cause a limit of the size of zirconium oxide particles, can provide a stimulus to explore this issue. The use, instead of water, volatile organic solvents, having a lower polarity than water, is also a direction of development of nano compound synthesis methods. We cannot determine which method of synthesis is the best because, when considering this issue, the following should be taken into account: access to equipment and chemical reagents, any financial outlay and predispositions as well as skills of people involved in the synthesis. The choice of synthesis methods can also be determined by the type of final material, e.g. powder or layered material.

\section{References}

[1] Pulit J., Banach M., Kowalski Z., Chemical reduction as the main method for obtaining nanosilver, Journal of Computational Theoretical Nanoscience 10, 2, 2013, 276-284.

[2] Marzec A., Pulit J., Kwaśny J., Banach M., Nanometale-wybrane technologie wytwarzania, Technical Translations vol. 1-Ch/2012, 95-107.

[3] Swihart M. T., Vapor-phase synthesis of nanoparticles, Current Opinion in Colloid and Interface Science 8, 2003, 127-133.

[4] Reguła T., Darłak P., Tchórz A., Lech-Grega M., Próba wytworzenia kompozytu na osnowie $\mathrm{Cu}_{x} \mathrm{Al}_{y}$ zbrojonego czasteczkami $\mathrm{Al}_{2} \mathrm{O}_{3}$ przy pomocy procesu mechanosyntezy, Prace Instytutu Odlewnictwa 1, 2010, 29-35.

[5] Goharshadi E. K., Hadadian M., Effect of calcination temperature on structural, vibrational, optical, and rheological properties of zirconia nanoparticles, Ceramics International 38 (3), 2012, 1771-1777. 
[6] Xie Z., Ma J., Xu Q. Huang Y., Cheng Y.-B., Effects of dispersants and soluble counter-ions on aqueous dispersability of nano-sized zirconia powder, Ceramics International 30, 2004, 219-224.

[7] Khare J., Srivastava H., Singh C.H.P., Joshi M.P., Kukreja L.M., Vapor phase synthesis of hexagonal shaped single crystal yttria stabilized zirconia nanoparticles using $\mathrm{CO}_{2}$ laser, Ceramics International 39, 2013, 1103-1109.

[8] Simchi A., Ahmadi R., Seyed Reihani S.M., Mahdavi A., Kinetics and mechanisms of nanoparticle formation and growth in vapor phase condensation process, Materials and Design 28, 2007, 850-856.

[9] Vasilyeva E.S., Tolochko O.V., Kim B.K., Lee D.W., Kim D.S., Synthesis of tungsten disulphide nanoparticles by the chemical vapor condensation method, Microelectronics Journal 40, 2009, 687-691.

[10] Gavillet J., Belmonte T., Hertz D., Michel H., Low temperature zirconia thin film synthesis by a chemical vapour deposition process involving $\mathrm{ZrCl}_{4}$ and $\mathrm{O}_{2}-\mathrm{H}_{2}-\mathrm{Ar}$ microwave postdischarges. Comparison with a conventional CVD hydrolysis process, Thin Solid Films 301, 1997, 35-44.

[11] Srdic V.V., Winterer M., Miehe G., Hahn H., Different zirconia-aluminia nanopowders by modifications of chemical vapour synthesis, Nanostructured Materials 12, 1999, 95-100.

[12] Choi H.-S., Ryu C.-H., Hwang G.-J., Obtention of $\mathrm{ZrO}_{2}-\mathrm{SiO}_{2}$ hydrogen permselective membrane by chemical vapor deposition method, Chemical Engineering Journal 232, 2013, 302-309.

[13] Jiang J., Shen W., Hertz J.L., Fabrication of epitaxial zirconia and ceria thin films with arbitrary dopant and host atom composition, Thin Solid Films 522, 2012, 66-70.

[14] Yeh T.-H., Lin R.-D., Cherng J.-S., Significantly enhanced ionic conductivity of yttriastabilized zirconia polycrystalline nano-film by thermal annealing, Thin Solid Films 544, 2013, 148-151.

[15] Hass D.D., Zhao H., Dobbins T., Allen A.J., Slifka A.J., Wadley H.N.G., Multi-scale pore morphology in directed vapor deposited yttria-stabilized zirconia coatings, Materials Science and Engineering A 527, 2010, 6270-6282.

[16] Li H., Khor K.A., Kumar R., Cheang P., Characterization of hydroxyapatite/nano-zirconia composite coatings deposited by high velocity oxy-fuel (HVOF) spray process, Surface and Coatings Technology 182, 2004, 227-236.

[17] Joulia A., Bolelli G., Gualtieri E., Lusvarghi L., Valeri S., Vardelle M., Rossignol S., Vardelle A., Comparing the deposition mechanisms in suspension plasma spray (SPS) and solution precursor plasma spray (SPPS) deposition of yttria-stabilised zirconia (YSZ), Journal of the European Ceramic Society 34, 2014, 3925-3940.

[18] Dong H., Yang G.-J., Cai H.-N., Li C.-X., Li C.-J., Propagation feature of cracks in plasmasprayed YSZ coatings under gradient thermal cycling, Ceramics International 41, 2015, 3481-3489.

[19] Dong H., Yang G.-J., Cai H.-N., Ding H., Li C.-X., Li C.-J., The influence of temperature gradient across YSZ on thermal cyclic lifetime of plasma-sprayed thermal barrier coatings, Ceramics International 41, 2015, 11046-11056. 
[20] Gao L., Wei L., Guo H., Gong S., Xu H., Deposition mechanisms of yttria-stabilized zirconia coatings during plasma spray physical vapor deposition, Ceramics International 42, 2016, $5530-5536$.

[21] Smits K., Grigorjeva L., Millers D., Kundzins K., Ignatans R., Grabis J., Monty C., Luminescence properties of zirconia nanocrystals prepared by solar physical vapor deposition, Optical Materials 37, 2014, 251-256.

[22] Bernard O., Huntz A.M., Andrieux M., Seiler W., Ji V., Poissonnet S., Synthesis, structure, microstructure and mechanical characteristics of MOCVD deposited zirconia films, Applied Surface Science 253, 2007, 4626-4640.

[23] Hemmer E., Kumakiri I. et al., Nanostructured $\mathrm{ZrO}_{2}$ membranes prepared by liquidinjection chemical vapor deposition, Microporous and Mesoporous Materials 163, 2012, 229-236.

[24] Shi G., Yu F., Wang Y., Li R., Synthesis of growth-controlled $\mathrm{ZrO}_{2}$ nanocrystals via vapor phase hydrolysis, Ceramics International 40, 2014, 13083-13088.

[25] Djurado E., Dessemond L., Roux C., Phase stability of nanostructured tetragonal zirconia polycrystals versus temperature and water vapor, Solid State Ionics 136-137, 2000, 1249-1254.

[26] Liu S., Jiang K., Zhang H., Liu Y., Zhang L., Su B., Liu Y., Nano-nano composite powders of lanthanum-gadolinium zirconate and gadolinia-stabilized zirconia prepared by spray pyrolysis, Surface \& Coatings Technology 232, 2013, 419-424.

[27] Amézaga-Madrid P., Hurtado-Macías A., Antúnez-Flores W., Estrada-Ortiz F., Pizá-Ruiz P., Miki-Yoshida M., Synthesis, microstructural, optical and mechanical properties of yttria stabilized zirconia thin films, Journal of Alloys and Compounds 536S, 2012, S412-S417.

[28] Tao K., Dou H., Sun K., Interfacial coprecipitation to prepare magnetite nanoparticles: Concentration and temperature dependence, Colloids and Surfaces A: Physicochem. Eng. Aspects 320, 2008, 115-122.

[29] Chen Q. Rondinone A.J., Chakoumakos B.C., Zhang Z.J., Synthesis of superparamagnetic $\mathrm{MgFe}_{2} \mathrm{O}_{4}$ nanoparticles by coprecipitation, Journal of Magnetism and Magnetic Materials 194, 1999, 1-7.

[30] Song J.E., Lee D.K., Kim H.W., Kim Y.I., Kang Y.S., Preparation and characterization of monodispersed indium-tin oxide nanoparticles, Colloids and Surfaces A: Physicochem. Eng. Aspects 257-258, 2005, 539-542.

[31] Benavente R., Salvador M.D., Alcázar M.C., Moreno R., Dense nanostructured zirconia compacts obtained by colloidal filtration of binary mixtures, Ceramics International 38, 2012, 2111-2117.

[32] Chang Q. Zhou J., Wang Y., Meng G., Formation mechanism of zirconia nano-particles containing pores prepared via sol-gel-hydrothermal method, Advanced Powder Technology 21, 2010, 425-430.

[33] Chintaparty R., Palagiri B., Nagireddy R.R., Immareddy V.R., Madhuri W., Effect of $p H$ on structural, optical and dielectric properties of nano-zirconium oxide prepared by hydrothermal method, Materials Letters 161, 2015, 770-773. 
[34] Kumar R. V., Ghoshal A.K., Pugazhenthi G., Fabrication of zirconia composite membrane by in-situ hydrothermal technique and its application in separation of methyl orange, Ecotoxicology and Environmental Safety 121, 2015, 73-79.

[35] Yoshimura M., Sōmiya S., Hydrothermal synthesis of crystallized nano-particles of rare earth-doped zirconia and hafnia, Materials Chemistry and Physics 61, 1999, 1-8.

[36] Chang Q. Zhou J., Wang Y., Meng G., Preparation and characterization of unique zirconia crystals within pores via a sol-gel-hydrothermal method, Advanced Powder Technology 20, 2009, 371-374.

[37] Behbahani A., Rowshanzamir S., Esmaeilifar A., Hydrothermal synthesis of zirconia nanoparticles from commercial zirconia, Procedia Engineering 42, 2012, 908-917.

[38] Huang H.-L., Cao G.Z., Shen I.Y., Hydrothermal synthesis of lead zirconate titanate (PZT or $\left.\mathrm{Pb}\left(\mathrm{Zr}_{0.52} \mathrm{Ti}_{0.48}\right) \mathrm{O}_{3}\right)$ nano-particles using controlled ramping and cooling rates, Sensors and Actuators A 214, 2014, 111-119.

[39] Ji X., Liu C. et al., Lauric acid template synthesis of thermally stable lamellar crystalline zirconia via a reflux-hydrothermal route, Materials Letters 122, 2014, 309-311.

[40] Chintaparty C. R., Influence of calcination temperature on structural, optical, dielectric properties of nano zirconium oxide, Optik 127, 2016, 4889-4893.

[41] Ao H., Liu X., Zhang H., Zhou J., Huang X., Feng Z., Xu H., Preparation of scandia stabilized zirconia powder using microwave-hydrothermal method, Journal of Rare Earths $33,7,2015,746-751$.

[42] Li C., Li K., Li H., Zhang Y., Ouyang H., Liu L., Sun C., Effect of reaction temperature on crystallization of nanocrystalline zirconia synthesized by microwave-hydrothermal process, Journal of Alloys and Compounds 561, 2013, 23-27.

[43] Porębska K., Powtokihydrofobowe na baize SiO ${ }_{2}$ wytwarzane metodązol-żel, Budownictwo i Architektura 12(4), 2013, 257-267.

[44] Walczak M., Charakterystyka powtok ceramicznych $\mathrm{SiO}_{2}$ i $\mathrm{SiO}_{2}-\mathrm{TiO}_{2}$ otrzymywanych metodą zol-żel, Postępy Nauki i Techniki 9, 2011, 80-90.

[45] Persson C., Unosson E., Ajaxon I., Engstrand J., Engqvist H., Xia W., Nano grain sized zirconia-silica glass ceramics for dental applications, Journal of the European Ceramic Society 32, 2012, 4105-4110.

[46] Mishra M.K., Tyagi B., Jasra R.V., Synthesis and characterization of nano-crystalline sulfated zirconia by sol-gel method, Journal of Molecular Catalysis A: Chemical 223, 2004, 61-65.

[47] Akkari R., Ghorbel A., Essayem N., Figueras F., Synthesis and characterization of mesoporous silica-supported nano-crystalline sulfated zirconia catalysts prepared by a solgel process: Effect of the S/Zr molar ratio, Applied Catalysis A: General 328, 2007, 43-51.

[48] Dela Rosa J.R., Hernandez A., Rojas F.,LedezmaJ.J., Sol-gel synthesis and characterization of novel La, Mn and Fe doped zirconia: Catalytic combustion activity of trichloroethylene, Colloids and Surfaces A: Physicochem. Eng. Aspects 315, 2008, 147-155.

[49] López-Quintela M.A., Tojo C., Blanco M.C., García Rio L., Leis J.R, Microemulsion dynamics and reactions in microemulsions, Current Opinion in Colloid \& Interface Science 9, 2004, 264-278. 
[50] Malik M.A., Wani M.Y., Hashim M.A., Microemulsion method: A novel route to synthesize organic and inorganic nanomaterials, Arabian Journal of Chemistry 5, 2012, 397-417.

[51] Margulis-Goshen K., Magdassi S., Organic nanoparticles from microemulsions: Formation and applications, Current Opinion in Colloid \& Interface Science 17, 2012, 290-296.

[52] Sanchez-Dominguez M., Pemartin K., Boutonnet M., Preparation of inorganic nanoparticles in oil-in-water microemulsions: $A$ soft and versatile approach, Current Opinion in Colloid \& Interface Science 17, 2012, 297-305.

[53] Duan G.-R., Yang X.-J., Huang G.-H., Lu L.-D., Wang X., Water/span80/Triton X-100/nhexyl alcohol/n-octane microemulsion system and the study of its application for preparing nanosized zirconia, Materials Letters 60, 2006, 1582-1587.

[54] Tai C. Y., Hsiao B.-Y., Chiu H.-Y., Preparation of spherical hydrous-zirconia nanoparticles by low temperature hydrolysis in a reverse microemulsion, Colloids and Surfaces A: Physicochem. Eng. Aspects 237, 2004, 105-111.

[55] López-Quintela M.A., Rivas J., Blanco M.C., Tojo C., Synthesis of nanoparticles in microemulsions, [in:] L. M. Liz-Marzán, P. V. Kamat (Eds.), Nanoscale Materials, Springer US, 2003, 135-155.

[56] Witek E., Kochanowski A., Pazdro M., Bortel E., Mikroemulsje jako źródło nanolateksów i nanoreaktorów, Polimery 51, 2006, 507-516.

[57] Zhou M., Xu L. et al., Investigation on the preparation and properties of monodispersed $\mathrm{Al}_{2} \mathrm{O}_{3}-\mathrm{ZrO}_{2}$ nanopowder via Co-precipitation method, Journal of Alloys and Compounds 678, 2016, 337-342.

[58] Hsu Y.-W., Yang K.-H., Chang K.-M., Yeh S.-W., Wang M.-C., Synthesis and crystallization behavior of 3 mol\% yttria stabilized tetragonal zirconia polycrystals (3Y-TZP) nanosized powders prepared using a simple co-precipitation process, Journal of Alloys and Compounds 509, 2011, 6864-6870.

[59] Lan L., Chen S., Cao Y., Zhao M., Gong M., Chen Y., Preparation of ceria-zirconia by modified coprecipitation method and its supported Pd-only three-way catalyst, Journal of Colloid and Interface Science 450, 2015, 404-416.

[60] Aruna S.T., Arul Paligan B., Balaji N., Praveen Kumar V., Properties of plasma sprayed $y$ ttria stabilized zirconia thermal barrier coating prepared from co-precipitation synthesized powder, Ceramics International 40, 2014, 11157-11162.

[61] Wang S., Li X., Zhai Y., Wang K., Preparation of homodispersed nano zirconia, Powder Technology 168, 2006, 53-58.

[62] Dudnik E.V., Modern methods for hydrothermal synthesis of $\mathrm{ZrO}_{2}$-based nanocrystalline powders, Powder Metallurgy and Metal Ceramics 48, 3-4, 2009, 238-248.

[63] Caillot T., Salama Z., Chanut N., Cadete Santos Aires F.J., Bennici S., Auroux A., Hydrothermal synthesis and characterization of zirconia based catalysts, Journal of Solid State Chemistry 203, 2013, 79-85.

[64] Montazerian M. et al., Bioactivity and cell proliferation in radiopaque gel-derived CaO$\mathrm{P}_{2} \mathrm{O}_{5}-\mathrm{SiO}_{2}-\mathrm{ZrO}_{2}$ glass and glass-ceramic powders, Materials Science and Engineering $\mathrm{C}$ 55, 2015, 436-447. 
[65] Montazerian M. et al., Sol-gel synthesis, structure, sintering and properties of bioactive and inert nano-apatite-zirconia glass-ceramics, Ceramics International 41, 2015, 11024-11045.

[66] Miyoshi S., Akao Y., Kuwata N., et al., Water uptake and conduction property of nanograined yttria-doped zirconia fabricated by ultra-high pressure compaction at room temperature, Solid State Ionics 207, 2012, 21-28.

[67] You H.C., Chang C.-M., et al., Facile preparation of sol-gel-derived ultrathin and high-dielectric zirconia films for capacitor devices, Applied Surface Science 258, 2012, 10084-10088.

[68] Díaz-Parralejo A., Macías-García A., Sánchez-González J., Díaz-Díez M.Á., Cuerda-Correa E.M., Influence of the experimental parameters on the synthesis process of yttriadoped zirconia sol-gel films, Surface \& Coatings Technology 204, 2010, 2257-2261.

[69] Boutonnet M, Kizzling J, Stenius P, The preparation of monodisperse colloidal metal particles from microemulsions, Colloids and Surfaces 5, 1982, 209-225.

[70] Ma T., Huang Y., YangJ.,HeJ.,Zhao L., Preparation of sphericalzirconia powder in microemulsion system and its densification behavior, Materials and Design 25, 2004, 515-519.

[71] Lee M.H., Tai C.Y., Lu C.J., Synthesis of spherical zirconia by precipitation between two water/oil emulsions, Journal of the European Ceramic Society 19, 1999, 2593-2603.

[72] Tai C.Y., Lee M.H., Wu Y.C., Control of zirconia particle size by using two-emulsion precipitation technique, Chemical Engineering Science 56, 2001, 2389-2398.

[73] Qiu H.B., Gao L., Qiao H.C., Guo J.K., Yan D.S., Nano-crystalline zirconia powder processing through innovative wet-chemical methods, Nanostructured Materials 6, 1995, 373-376. 